Article

\title{
Are Well Owners Unique Environmentalists? An Exploration of Rural Water Supply Infrastructure, Conservation Routines, and Moderation
}

\author{
Brock Ternes \\ Department of Sociology/Anthropology, State University of New York College at Cortland, \\ Cortland, NY 13045, USA; brock.ternes@cortland.edu
}

Received: 4 August 2019; Accepted: 1 September 2019; Published: 4 September 2019

check for updates

\begin{abstract}
Enormous demands for irrigation water have depleted groundwater reserves in Kansas, where portions of the High Plains aquifer are in jeopardy. This study examines how private water wells influence conservation routines by comparing the watering practices of well owners to those of non-well owners across the state. My guiding research question is: Does water supply infrastructure moderate the relationship between demographic predictors and pro-environmental behaviors (PEBs)? To answer this, I surveyed well owners and non-well owners throughout Kansas $(\mathrm{n}=864)$. The results indicate that controlling for water supplies uncovers differences across many associations between water conservation efforts and other PEBs with commonly studied demographics (sex, income, political affiliation, education, age, and geography). Researching well owners' acts of environmental stewardship will be key to aquifer preservation.
\end{abstract}

Keywords: well owners; pro-environmental behaviors; groundwater; infrastructure; sociology of water usage

\section{Introduction}

Groundwater declines are a leading cause of water shortages in many of the planet's most water-stressed areas [1]. Aquifers (underground reservoirs of freshwater) are a critical supply of freshwater and remain a crucial defense against droughts. Globally, groundwater plays a critical role in sustaining agriculture and drinking water, but researchers anticipate that overstressed aquifers will be in even greater demand as climate change continues to increase the severity of droughts [2]. All over the world, farms and communities depend on groundwater, and enduring surface water deficits will necessitate enlarged extractions from overdrafted aquifers [3]. Anthropogenic warming is projected to ramp up the incidence of megadroughts, decades-long spans of penetrating aridity [4], which would apply additional pressure on groundwater reserves.

One of the largest aquifers in the world, the High Plains aquifer in the central United States (see Figure 1 [5]), has undergone severe declines on account of the rapid extractions from multitudinous irrigation wells. The imbalance between overdrafts (removals of water out of an aquifer faster than it can be regained), and recharge (the natural percolation of surface water into aquifers) has been so severe that the central and southern portions of the aquifer are experiencing enormous declines [6]. The state of Kansas's portion of the High Plains aquifer contains some of the worst recharge-to-extraction ratios in the entire region and low recharge rates make parts of the aquifer essentially nonrenewable [7]. Nearly one-third of the aquifer's water has been extracted since the mid-twentieth century, and if current rates of extraction continue, the aquifer will be 69 percent depleted by 2060 [8].

The High Plains aquifer has been mined by tens of thousands of irrigation wells for seventy years; the region over the aquifer comprises the largest irrigation-sustained cropland on the planet [9]. 
It produces more than $\$ 20$ billion worth of crops each year [10], but unless withdrawals are seriously curtailed, Kansas will remain "extremely vulnerable to drought" [11]. The climate of the High Plains is projected to produce warmer droughts, which have greater intensity and imply that states like Kansas will be even more reliant on dwindling groundwater supplies to meet their needs [12].

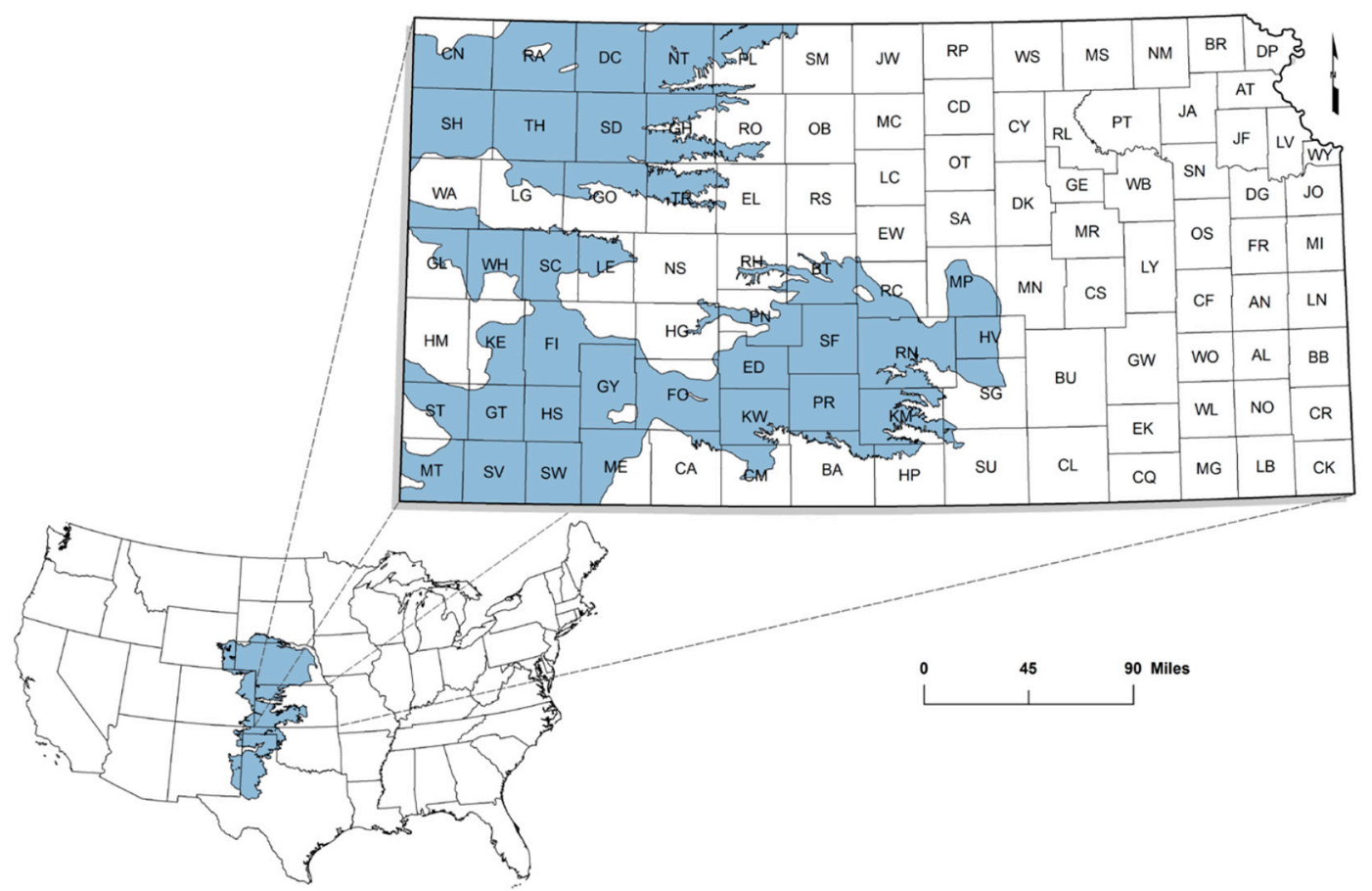

Figure 1. The High Plains aquifer [5].

The influence of structural conditions on environmental behaviors is especially important in the High Plains, where communities are highly dependent on groundwater and have vested interests in water conservation. Contextualizing watering practices within specific groundwater formations and infrastructural systems can improve water management research. This study examines Kansans' notions of environmentalism and reveals how respondents' water supplies shape their watering practices and pro-environmental behaviors (PEBs). Specifically, it assesses Kansans' propensity to engage in water conservation and other PEBs. Aquifers and well owners (individuals with private supplies that extract groundwater) constitute an interconnected socio-ecological system, and researching well owners' water conservation efforts (and other forms of environmentalism) will be essential for aquifer preservation.

Sustaining the High Plains aquifer requires an investigation of the individuals reliant on its groundwater. This research probes how water supply infrastructure is associated with conservation routines. Generally, the paper explores how well owners' practices are contoured by their distinctive reliance on groundwater, while asking: Is the relationship between commonly studied demographic variables and PEBs moderated by water supply infrastructure? It hypothesizes that the relationship between demographic predictors (including sex, income, political affiliation, education, age, and geography) and acts of environmentalism will be influenced by whether Kansans rely on public or private water supplies. The project seeks to augment PEB research by investigating water conservation efforts (and other PEBs) among well owners and non-well owners in Kansas, thereby connecting demographic predictors to behaviors while controlling for differences in water supply infrastructure. By studying well owners as a group embedded within a unique system of water provision, this research assesses how differing infrastructural contexts explain varying performances of environmentalism.

Understanding the influence of water supply infrastructures on conservation efforts will be critical for the resilience of populations overlying aquifers, especially in rural communities, since groundwater is the drinking water source for 90 percent of the rural population in the United States and 80 percent of 
rural Canadians [13,14]. Private well owners are susceptible to groundwater contamination and reduced well yields, and they are disproportionately burdened by groundwater loss compared to citizens with municipally-provided water. The next section outlines the literature on PEBs, water supply infrastructure and consumption; it shows how water conservation has been widely studied and theories of practice can be applied to such behaviors. Nevertheless, empirical reflection evaluating water infrastructure as a source of variation in rural PEBs remains limited, as sustainable practices literature has not sufficiently assimilated rural water systems. This project expands the frontiers of the sociology of water use by studying how infrastructure is applied to the subfield. Household characteristics, theories of sustainable practices, and social contexts have all been considered by sociologists, but private infrastructure and groundwater reliance have not. In the hopes of bringing water supply infrastructure into the purview of PEB scholarship, this article facilitates how the field incorporates water supplies into its analysis by identifying how water supplies influence the ability to predict the adoption of sustainable practices.

\section{Literature Review and Framing}

Too many studies to list focus on the influential factors of individual PEBs (commonplace efforts to save the environment) and the sociodemographics affecting environmental concern. While PEBs can include civic actions like signing petitions, marching, and policy support, individual or household-based PEBs like recycling, conserving energy, and buying green or organic goods are the most commonly studied. A number of scholars use quantitative methods to develop measures of environmental awareness, conservation attitudes, and pro-environmental attitudes and behaviors [15-19]. One common metric for environmental action is the integration of multiple survey items related to a variety of environmental behaviors, since research suggests that environmentalist actions tend to be correlated with each other. For instance, recycling, buying organic foods, using public transportation, and other pro-environmental behaviors are connected. These co-variances are known as environmentalist "spill-over effects" [20,21].

What encourages behaviors that benefit the environment? Researchers have long assessed PEBs with demographic variables (e.g., sex, class, political affiliation). The implementation of each PEB is complicated, and a variety of statistically modeled theories seek to explain PEBs. Kennedy and Givens [22] hold that those who prefer to engage in green consumption express stronger environmental concerns, and those concerns are driven by individuals' ability to participate in ecofriendly behaviors. Research in Feminist Political Ecology underscores the linkages between water consumption, gender, and class [23]. Women adopt private-sphere pro-environmental behaviors (recycling, saving water, buying organic) more readily than men, making household environmental responsibilities feminized tasks [24,25]. Sustainable practices literature has determined, "change to lifestyles requires similar changes to an individual's volumes of resources, and to the infrastructural and material arrangements that constrain consumption" [26]. Nevertheless, insufficient PEB research has considered the influence of water supply infrastructure.

Water provided by public suppliers reaches a majority of people in the United States, roughly 268 million, while self-supplied sources provide nearly 45 million Americans with their domestic water [27]. Centralized sewage treatment centers and drinking water supplies differentiate the hydrologic backgrounds of urban and rural communities. During the urbanization of the United States (roughly 1790 to 1870), advanced hydraulic engineering and hidden infrastructures enabled a cultural rethinking of water: it was to be readily available in urban hubs [28]. Conversely, rural water landscapes are dominated by groundwater extractions from local, private wells that require individual monitoring and maintenance; well owners perennially evaluate agricultural runoff, well yields, pumping costs, depth to the water table, and water quality $[29,30]$.

The development of water infrastructure exemplified how cultural beliefs and priorities manifest themselves in the built environment. Cities form an "infrastructure of ideas" [28], an arrangement of political, economic, and social institutions. Brown's work on water conservation policies expounds 
how water supplies are socially constructed: "the configurations are the product of public policy, cultural values, and political and economic relations" [31]. The social and physical layouts of cities are inseparable because hydraulic engineering projects are embodiments of the city's resource management priorities, and these infrastructures encourage consumption by drawing on distant bodies of freshwater to make water accessible for large populations. Fine [32] refers to the institutional arrangements, technologies, and activities that unite to provide a service as "systems of provision." Water can come from municipal systems or private wells, and this research explores how different systems of provision contour patterns of water conservation and other everyday PEBs. As systems of provision remain central to enacting everyday behaviors, individuals become "undeniably part of these systems ... when they are reshaped, parts of our lives are reshaped" [33]. It is important to consider the effects of water distribution networks that make the patterns of domestic water consumption possible, and I apply this idea to analyze watering and conservation practices, and well ownership.

Sociologists have used systems of provision to frame the infrastructural and social arrangements in which water consuming practices are embedded [34], but "infrastructure" is largely taken for granted as "municipal supplies." The existing infrastructures in rural communities constitute rural water systems and private wells, but have not been fully incorporated into the literature associated with sustainable practices. As infrastructure augmented cities' water supplies, everyday life embodied different understandings of health, cleanliness, and leisure, as the provision of clean water changed its symbolic significance [35]. With the arrival of water connections in the households of cities in Europe and the United States starting around 1860, bathing moved from public bathhouses to private households; it became a routine associated with private, leisurely cleaning and relaxation [36]. In the following decades, bathrooms, bathing, and cleanliness came to be means of impressing guests and displaying good taste, and household connections to municipal water allowed for a remarkable spike in practices embedded with water usage. It only took a couple years in the early 1920s for Americans to double their number of baths [36], as household water connections seemed to erase the previous centuries of water scarcity and usher in an "age of easy water-an era of plentiful, reliable supplies of clean water, accessible to population centers" [37]. Such changes suggest that water delivery systems are connected to water consumption and socially transmittable standards of sanitation.

Elisabeth Heidenreich's [38] concept of flow spaces connects technology, cultural ideals, and materials. She contends that the development of waterworks led to a shift towards more individualized experiences of resource use for personal pleasure. The consumption of water increased as people attached status to cleanliness and hygiene [26,39]). Water use in municipalities became a source of hygiene routines and "a marker of civilization ... Access to water ... implied much greater volumes of water use than in the past" [40]. Generally, the elaborate infrastructure behind modern, improved drinking sources led to a reconceptualization of water: its perceived abundance led to its extravagant usage.

Given this backstory, it appears that as supplies vary, so do demands-but private wells constitute a system of water provision that has been overlooked within the sociology of water usage. Investigations of showering behaviors actually omitted households with internally-plumbed private supplies (like rainwater tanks) and only examined residences with municipal utilities [41]. Private water supplies are missing from the body of literature on domestic watering practices, and the ability to predict PEBs, like conserving water around the house, could be improved by assessing alternative water supply infrastructures. Investigating water supply systems, and their associated standards of usage, expands research on environmental infrastructure, which has focused primarily on urban centers struggling to meet the demands of their growing populations. Overall, private and public water sources could engender different standards of consumption. Since well owners rely directly on aquifers, they can take on the identity of groundwater managers [42]. Well owners are responsible for their water supply in a way that recipients of municipally-provided water are not: their daily water usage affects their own source of groundwater. This relationship could realistically foster a sense of groundwater stewardship and change the propensity towards sustainable action. 
Drawing from infrastructural scholarship, PEB literature, and practice theories, I assess water conservation among Kansans with different water supply systems. As the High Plains climate tilts towards harsher, longer droughts, rural communities must precisely understand well owners' conservation efforts. Prior studies have made valuable contributions, but less attention has been paid to water supply infrastructure as a basis of differentiation in watering practices. This paper assesses the effects of exogenous predictors on PEBs while comparing well owners and non-well owners in Kansas, hypothesizing that the relationship between demographic predictors and deliberate conservation behaviors will be moderated by water supplies. The project collected information from well-owning and non-well-owning Kansans via an online survey to effectuate a moderation test.

\section{Data Collection, Sample Overview, and Methods}

In order to study the effects of well ownership, 7021 notification postcards were mailed to invite Kansas well owners to participate in an online survey that measures their household water supply, prioritization of water conservation efforts, and frequencies of various PEBs. The well owners' home addresses were culled from a database of well completion records run by the Kansas Geological Survey. Most of the non-well owners' surveys came from a panel of 420 Kansans collected by the online survey company Qualtrics, which uses Survey Sample International's (SSI) multi-sourcing panel recruitment model to generate representative random samples.

This survey produced a rare quantitative dataset on well owners. Survey responses were collected in 2015; the postcards sent to well owners had a response rate of 6.3 percent, providing 444 respondents. The dataset includes 864 respondents, 452 non-well owners (52 percent) and 412 well owners. Of those well owners, 20 are former well owners, 143 are without municipal water supplies, and 249 have both wells and municipal water. Forty-four percent of respondents live above the High Plains aquifer. While three-quarters (74 percent) of the non-well owners in the sample live outside the High Plains aquifer, a majority of well-owning respondents (57 percent) overlie it. The survey received replies from 93 of the 105 counties in Kansas.

This sample has a balanced sex distribution; men comprise 48 percent of the respondents. Well owners' mean age is 57 , compared to 46 for non-well owners. These demographics mirror previous focus groups of well owners, which also had older, male majorities [43]. Well owners are slightly more educated than non-well owners. The modal income category for non-well owners is $\$ 20,000-39,999$, while well owners without municipal water connections have bimodally distributed income; $\$ 40,000-59,999$ and $\$ 150,000$ or more are the most common ranges of household earnings. Well owners with access to municipal water are also wealthier than non-well owners, as their modal household income range is $\$ 100,000-149,999$. These numbers align with previous research, which notes wide variance in well users' incomes-although that is only known anecdotally and there are not many sociodemographic studies of well owners [44,45]. Slight political differences can be detected across these groups. Well owners most frequently describe their political views as "conservative" while non-well owners' modal description is "moderate."

For analysis, multigroup regressions were performed demarcating respondents with a well owner/non-well owner dichotomy. Other scholars have employed similar analyses to look into the effect of moderators for PEBs [46] and environmental concern [47]. Given that my framing hinges on the differences in water provision, this research assesses Kansans' conservation of water within different infrastructural contexts.

\section{Multigroup Data and Moderation}

Does conservation change across groups when organizing Kansans by their water supplies? To build on extant research, this paper assesses how water supplies might moderate the relationships of sociodemographic variables on PEBs, which has not been previously examined. I employ multigroup regression to reveal how correlations vary across groups of well ownership. Conceptualizing watering practices as nested behaviors is exceptionally apposite because groundwater communities reside 
within larger hydrologic and agronomic systems: they inhabit particular infrastructural settings, experience different levels of overdrafting and recharge, and reside above specific supplies of groundwater. Analyzing Kansans without considering the nested effects of water supplies ignores the glaring infrastructural differences outlined earlier in the paper; this research clarifies how acts of environmentalism are embedded in unique systems of provision.

The research agenda hypothesizes that the relationship between predictors and PEBs will be moderated by the presence or absence of a well. Moderation, therefore, is an important causal effect central to water-related discussions and management. The relationship between independent predictors (including sex, income, political affiliation, education, age, and geography) and dependent variables (frequency of deliberately saving water around the house, ranking water security as a challenge facing Kansas, voting on water-related policies in local and state elections, frequencies of recycling, frequencies of using reusable shopping bags, and frequencies of composting) is hypothesized to be moderated by water supply infrastructure. This hypothesis foresees nuanced relationships between sustainable watering practices and reliance on wells. Studies of water management submit that different groups have different interests in conserving a particular water supply, "Different systems of provision create different forms of demand" [34,48]. Moderation should therefore be expected and empirically demonstrated across the two groups.

\section{Results}

The independent variables (sex, income, political affiliation, education, age, and geography) are correlated with various dependent measures of conservation efforts (frequency of deliberately saving water around the house, ranking water security as a challenge facing Kansas, voting on water-related policies in local and state elections, frequencies of recycling, frequencies of using reusable shopping bags, and frequencies of composting) by running multigroup regressions for well owners and non-well owners. Table 1 shows the beta coefficients of the outcome variables measuring water conservation and environmentalism regressed on predictors for non-well owners and well owners, and provides evidence that some of these relationships are moderated by well ownership (the moderated relationships are italicized; Table 1 focuses on the differences in slopes across groups). Please consult the Appendix A to learn how the dependent variables were operationalized.

Sex. How do the relationships between respondents' sex and water conservation efforts change when controlling for water supply infrastructure? In many respects, the non-well owning sample mirrors the well owning sample. For non-well owners, sex (female) is only significantly correlated with voting on water-related policies in local and state elections. Well owners show a significant negative relationship between being a woman and ranking water security as a political challenge facing Kansas, and voting on water-related policies. Overall, well ownership does not appear to influence the significance of correlations between sex and frequency of deliberate water savings, voting on water-related policies, or frequencies of recycling, using reusable shopping bags, and composting.

Income. Income is not significantly associated with any of the dependent variables for well-owning Kansans, and isolating the well owners shows slight evidence of the moderating effect of infrastructure on income and water conservation. For non-well owners, income is positively associated with voting on water-related policies and recycling frequency. Interestingly, while income has a positive, significant effect with those dependent variables for non-well owners, it does not for the well owners. To a certain extent, the positive association between income and two of the PEBs is echoed in prior research which outlines that engagements of environmental protection are most commonly practiced by high-status individuals [49].

Political conservativism. Controlling for well ownership changes a few associations of Kansans' political views with the dependent variables. Political conservativism is not significantly correlated with voting on water policy, frequency of using reusable grocery bags, or frequency of composting for neither non-well owners nor well owners. Recycling is negatively associated with political conservativism for well owners, but the relationship is not significant for non-well owners. While political conservatism is 
positively associated with deliberately saving water for well owners, the relationship is not statistically significant for non-well owners.

Table 1. Multigroup standardized regression predicting the differences across demographic variables in water conservation and PEBs for non-well owners and well owners.

\begin{tabular}{|c|c|c|c|}
\hline & & Non-Well Owners & Well Owners \\
\hline Predictor & Sex (Female) & $B$ & $B$ \\
\hline \multirow{6}{*}{ Dependent Variables } & Frequency of deliberate water saving & 0.106 & 0.005 \\
\hline & Politically prioritizing water security & -0.085 & $-0.133 *$ \\
\hline & Voting on water-related policies & $-0.206^{* * *}$ & $-0.238^{* * *}$ \\
\hline & Frequency of recycling & -0.058 & 0.072 \\
\hline & Frequency of reusable grocery bags & 0.078 & 0.085 \\
\hline & Frequency of composting & 0.025 & 0.047 \\
\hline Predictor & Income & $B$ & $B$ \\
\hline \multirow{6}{*}{ Dependent Variables } & Frequency of deliberate water saving & -0.039 & -0.018 \\
\hline & Politically prioritizing water security & -0.032 & 0.012 \\
\hline & Voting on water-related policies & $0.147^{* *}$ & -0.010 \\
\hline & Frequency of recycling & $0.274^{* * *}$ & 0.016 \\
\hline & Frequency of reusable grocery bags & 0.042 & 0.068 \\
\hline & Frequency of composting & -0.041 & -0.092 \\
\hline Predictor & Political Views (conservative) & $B$ & $B$ \\
\hline \multirow{6}{*}{ Dependent Variables } & Frequency of deliberate water saving & -0.054 & $0.135 *$ \\
\hline & Politically prioritizing water security & $-0.115^{*}$ & $-0.132 *$ \\
\hline & Voting on water-related policies & -0.075 & 0.100 \\
\hline & Frequency of recycling & -0.049 & $-0.189 * *$ \\
\hline & Frequency of reusable grocery bags & -0.063 & -0.106 \\
\hline & Frequency of composting & -0.104 & -0.063 \\
\hline Predictor & Education & $B$ & $B$ \\
\hline \multirow{6}{*}{ Dependent Variables } & Frequency of deliberate water saving & -0.058 & -0.033 \\
\hline & Politically prioritizing water security & -0.063 & 0.032 \\
\hline & Voting on water-related policies & $0.203^{* * *}$ & 0.043 \\
\hline & Frequency of recycling & $0.198^{* * *}$ & $0.184^{* *}$ \\
\hline & Frequency of reusable grocery bags & 0.079 & 0.093 \\
\hline & Frequency of composting & 0.117 * & 0.081 \\
\hline Predictor & Age & $B$ & $B$ \\
\hline \multirow{6}{*}{ Dependent Variables } & Frequency of deliberate water saving & $0.217^{* * *}$ & 0.107 \\
\hline & Politically prioritizing water security & $0.135 *$ & 0.072 \\
\hline & Voting on water-related policies & $0.215^{* * *}$ & 0.043 \\
\hline & Frequency of recycling & $0.240^{* * *}$ & $0.140 *$ \\
\hline & Frequency of reusable grocery bags & $0.255^{* * *}$ & 0.048 \\
\hline & Frequency of composting & $0.116^{*}$ & 0.117 \\
\hline Predictor & Geography (Western Kansas) & $B$ & $B$ \\
\hline \multirow{6}{*}{ Dependent Variables } & Frequency of deliberate water saving & 0.101 & -0.108 \\
\hline & Politically prioritizing water security & 0.174 ** & $0.132 *$ \\
\hline & Voting on water-related policies & $0.148 * *$ & 0.114 \\
\hline & Frequency of recycling & -0.049 & $-0.120 *$ \\
\hline & Frequency of reusable grocery bags & -0.007 & $-0.153 *$ \\
\hline & Frequency of composting & -0.001 & $-0.178^{* *}$ \\
\hline
\end{tabular}

${ }^{*} p<0.05,{ }^{* *} p<0.01,{ }^{* * *} p<0.001$; italicized variables indicate moderation. For the sake of concision and ease of reading, only betas and significance values are provided in Table 1 . Standard errors and other statistics are available upon request. 
Education. Non-well owners show significant positive associations between education and voting on water policies in local or state elections, recycling, and composting. For well owners, education is not significantly correlated with most of the dependent variables; only recycling is positively correlated with education, as it was in the subsample of non-well owners. The other correlations measuring education's correlation to the dependent variables are not significant in the sample of well owners. As is the case with regressions using other predictors, conducting multigroup analysis provides evidence that owning a well changes the story of education's association with pro-environmental behaviors and water conservation efforts.

Age. A similar trend continues when age is the demographic predictor. Age is positively significantly associated with all of the dependent variables for the non-well owners in the dataset. For well owners, age is a less reliable determinant of the dependent variables; it is only a significant predictor for recycling frequencies. Age is no longer a significant predictor for most of the aforementioned relationships among the well-owning respondents, unlike the analyses on non-well owning sample, in which age is significantly and positively correlated to all the dependent variables.

Geography. Finally, the multigroup regressions control for differences in water supplies using geography (residence above the High Plains aquifer in western Kansas) as an independent variable. For non-well owners, living in western Kansas is significantly and positively correlated with prioritizing water security for the state and voting on water policies in local and state elections. For well owners, politically prioritizing water security is also significantly correlated with geography, but voting on water-related policies is not. Furthermore, while geography is not significantly correlated to recycling, using reusable bags, or composting, it is negatively and significantly correlated with those PEBs among Kansas well owners. All of these differences are evidence of moderation.

A key finding emerges from these regressions: well ownership changes many associations surrounding the predictors and conservation efforts. Specifically, the relationships between two independent variables (education and age) and the dependent variables measuring water conservation and PEBs are significant for non-well owners, but not statistically significant among well owners (with the exception of recycling frequencies). This insinuates that well ownership in Kansas weakens the relationships among commonly studied demographics and PEBs.

Overall, the analyses reveal that water supplies moderate several relationships associated with water consumption and sustainable practices, which suggests that infrastructure contextualizes the adoption of conservation habits and Kansans' notions of environmentalism are recalibrated by their systems of water provision. As discussed in the literature review, flow spaces, infrastructures of ideas, and systems of provision are important frameworks for understanding socially acceptable watering routines. What if infrastructure not only influences water conservation, but other conservation practices too? Would that mean that environmentalist spillovers are stylized by water systems?

Existing scholarship summarizes how everyday life was transformed by the installation of municipal waterworks. Those infrastructures appear to redefine natural resource consumption altogether-not just water consumption. This suggests that "flow spaces" [38] are not only spaces of water usage: they are spaces of distinct environmentalism. Previous research has uncovered significant associations between demographic predictors and deliberate conservation efforts; however, these findings suggest that controlling for water supplies leads to relevant discoveries. Can owning a well make people different environmentalists?

\section{Discussion: Well Owners as Environmentalists}

The results are obviously nuanced and multigroup regression produces many betas that are eligible for discussion. In the interest of brevity and crystallizing a central argument, this section will focus on a few well owner/non-well owner comparisons that amplify a main takeaway from the findings which suggest that rural water supplies instill a unique type of environmentalism.

According to recent research, well ownership is positively correlated with voting on water-related issues [42]; however, education is only significantly correlated to those voting patterns for non-well 
owners, not for well owners. Perhaps education enlightens non-well owners about state water law or improves their awareness of geology, but well owners could already be aware of water supplies regardless of their education levels. Maybe well-owning Kansans do not need a large investment in formal education to make informed voting decisions because of their unique reliance on groundwater-it is in their interest to understand policies that have implications for their private water supplies.

The evidence of public and private water supplies' moderating influence is clear when unpacking the relationship between age and the dependent variables. The relationship between age and PEBs is mostly moderated by water supplies: every slope between the predictors and PEBs is significant among the non-well owners, while all but one slope (recycling) is not statistically significant among the well owners. What explains these relationships' differing levels of significance? Like education, as non-well owners mature, perhaps they learn more about water-related issues facing Kansas. Younger Kansans without wells might not be aware of water saving strategies, composting, the political challenges facing Kansas, water policies, and so on. Age may not be significantly correlated with the dependent variables among well owners because well owners of all ages already have a clear understanding of water supplies and conservation efforts.

Recent scholarly work speaks to the connections between PEB adoption, education, and age in agricultural settings. Nguyen and colleagues [50] discovered that education and training improved farmers' efficiency: "Formal knowledge, indicated by the level of education of the head of the farm, had a significant positive impact on efficiency" (p. 8). Assuming that PEBs save resources and improve efficiency, life experience can likely be attributed to sustainable practices in rural settings. Alternatively, other scholars find a negative association between age and pro-environmental attitudes and less evidence that older generations-even cohorts which matured during the waves of environmental activism in the 1960s and 1970s-are environmentally focused [51]. Age remains an important control while modeling environmental beliefs.

Is it possible that a heightened sense of environmentalism is built into well ownership? To what extent does having a private water supply foster environmental ethics? Can owning a well grant someone a sense of wisdom or mindfulness? While Johnson and Schwadel [51] establish a decrease in support for environmental action among older respondents, they also state, "individuals may care less about the environment as they age because they are progressively less likely to be exposed to environmental ideology through engagement with social change actors or educational institutions" (p. 896). If this is true, and well owners of all ages consciously save resources, it suggests that the context of well ownership offers a type of didactic backdrop for citizens directly reliant on groundwater.

Staying perennially involved with aquifers could consequently foster an ethic of groundwater citizenship. Ternes [42] established that well owners have significantly higher levels of water literacy than non-well owners, which supports the larger argument that as water supply infrastructure changes, so does environmental awareness. That awareness could change more in the context of groundwater reliance than it does in educational contexts (as the education-PEB regression lines suggest). Liobikiene and Poskus [19] suggest that factual environmental knowledge promotes PEBs. Previous literature [52] demonstrates that individuals are more likely to engage in behaviors which are valued by their acquaintances and that social circles have a direct effect on sustainable routines. Network research [53] demonstrates that individuals with strong connections to their social group coordinate their actions with others. Such inquiries parallel work by Corral-Verdugo and colleagues [54], who suggest that conservation efforts only work if they are perceived to be shared by the entire community. The social norms of well owners are likely reasonable explanations for their adoption of PEBs, and proactive water management can be fostered by well owners, given that aquifers underpin the water systems of manifold rural areas in drought-prone regions.

Overall, most of the existing research in the sociology of water usage has focused on water consumption in urban contexts with public water supplies. This is not without cause, as sound water management and infrastructure will remain massive challenges for cities well into the future, "water has a critical role in supporting ... inclusive cities" [55,56]. These findings indicate that only analyzing 
non-well owners-omitting the influence of rural water supplies—offers an incomplete story of water conservation efforts and other PEBs. Citizens' practices are restricted by their material conditions, and reassessing the infrastructures in which watering practices are determined can advance environmental sociology towards more decisive endeavors that will augment communities' abilities to remain resilient during the looming droughts and heat waves of the Anthropocene.

This manuscript brings systems of water provision squarely into focus, something rarely done when empirically investigating watering practices. Unique combinations of circumstances (including water table declines, droughts, and water allocations) and infrastructures (such as publicly provided water and household plumbing) might lead people to prioritize water conservation and foster a variety of motivations to conserve resources. The study quantitatively assesses water conservation behaviors among Kansans with different water supply systems. As the climate of the Great Plains becomes less predictable, communities prone to drought must acquire a precise understanding of the public's concern about environmental problems to prepare for a new hydrologic reality defined by more frequent, intense water shortages. Many scholars have investigated infrastructure, PEBs, and well owners; I analyze them simultaneously.

Claiming that well owners are a distinct social group defined by their practices and their exposure to groundwater depletion appears to be accurate, but heavily nuanced. Well ownership is connected to unique relationships with water conservation, PEBs, and demographic predictors. Recent research [57] indicates that well function changes the associations between water supply awareness and water usage during droughts. Similarly, this study's findings reveal that household water supplies moderate watering routines; therefore, they should be included in PEB research. According to Little [58], a moderator refers to a variable that influences the relationship between other variables. He uses the following example: the relationship between an automobile's speed and the RPMs of its engine are moderated by the gear in which the vehicle is. This project's findings indicate that water supplies can be a gear for environmentalism in Kansas.

\section{Limitations}

These findings are only generalizable to the state of Kansas (and perhaps other High Plains states) but this research neither intends nor claims to offer an extensive representation of the influence of water supplies on PEBs. Conservation routines are nested within certain hydrological contexts, making generalizability at the national level an inappropriate goal for any assessment of watering practices. The performances of well owners and other Kansans are partially affected by the state's distinctive groundwater supplies and water-related policies. Nevertheless, this work is an adequate representation of watering routines and it delineates how PEBs are contoured by water supplies in Kansas.

Accurately capturing environmental practices via surveys can be difficult because respondents' answers can contradict manifest actions, creating an "attitude-behavior gap" [59] or "dual realities" [60] in which self-reported behavior and observed behavior do not match. Including more survey items tracking "everyday" routines could facilitate a comparison of the practices adopted by well owners and non-well owners. In any event, organizing Kansans along the divide of well ownership and access to municipal water exposes significant differences in environmental action. These results suggest that water supply infrastructure can be a notable component for predicting conservation routines, and well ownership seems to change the significance of some relationships between demographic predictors and PEBs.

\section{Conclusions}

Scrutinizing a survey of well owners and non-well owners, this paper demonstrates that reliance on private water supplies can serve as a useful moderator when analyzing the adoption of PEBs. Well ownership changes many associations between predictors and conservation efforts, which offers a nuanced counterpoint to previous work on PEBs: conservation routines arise within specific socio-ecological structures. These results suggest that relying on groundwater opens a doorway 
to understanding water conservation, and environmentalism at large. Groundwater losses are a recalcitrant climate change challenge, and given the reports of rapid groundwater depletion around the world, well ownership must be carefully analyzed. Examining water supply infrastructure adds complexity to investigations of rural communities, environmental practices, and resilience-building in the Anthropocene. These findings highlight how systems of water provision are an influential moderator that researchers examining resource management should consider.

Funding: This research was partially supported by the University of Kansas under the Doctoral Student Research Grant, the Institute for Policy \& Social Research at the University of Kansas under the Doctoral Research Fellows Grant, and the Faculty Development Center at SUNY Cortland.

Acknowledgments: The author effusively thanks Paul Stock, Bob Antonio, David Smith, Ebenezer Obadare, and Terry Loecke at the University of Kansas, and Todd Little at Texas Tech University. Thanks to Valerie Peterson, Cassie Butts, Sofiia Filatova, Yulduz Kuchkarova, Liz Blackburn, Halle McCourt, Katelyn Whitt, Chelsea Martell, and Murphy Maiden for their research assistance. The editorial staff and reviewers at Sustainability offered perceptive feedback on this manuscript and were extraordinarily punctual.

Conflicts of Interest: The author declares no conflicts of interest.

\section{Appendix A}

Survey Items and Responses

In the past year, how often did you deliberately try to save water around the house?
A. Never
B. Once or a few times over the year
C. Roughly once a month
D. Roughly once a week
E. Daily

Kansas faces a number of challenges. Please select the statement that best describes your attitude regarding the future of water in Kansas. (Reverse coded)

A. I believe that securing water for the future is one of the two or three most important issues facing our state

B. Securing water for the future is one issue facing our state I personally care about, but I can think of a handful of issues that are more important right now

C. There are many issues that I personally care more about than securing water for the future in Kansas

Have water policies affected how you voted in local elections or state elections? (Reverse coded)

A. Yes, in both local and state elections

B. Yes, only in local elections

C. Yes, only in state elections

D. No

E. I don't typically vote in local or state elections

How often do you recycle your glass, paper, newspaper, aluminum, plastic, and so forth?
A. Never
B. Occasionally
C. Most of the time
D. Nearly always or always 
How often do you use your own grocery bag when shopping?
A. Never
B. Occasionally
C. Most of the times that I shop
D. Every time I shop

How often do you compost your kitchen or garden waste?
A. Never
B. Occasionally
C. Most of the time
D. Nearly always or always

\section{References}

1. Richey, A.S.; Thomas, B.F.; Lo, M.H.; Reager, J.T.; Famiglietti, J.S.; Voss, K.; Swenson, S.; Rodell, M. Quantifying Renewable Groundwater Stress with GRACE. Water Resour. Res. 2015, 51, 5217-5238. [CrossRef] [PubMed]

2. James, F. The Global Groundwater Crisis. Nat. Clim. Chang. 2014, 4, 945-948.

3. Alley, W.M.; Rosemarie, A. High and Dry: Meeting the Challenges of the World's Growing Dependence on Groundwater; Yale University Press: New Haven, CT, USA, 2017.

4. Steiger, N.J;; Smerdon, J.E.; Cook, B.I.; Seager, R.; Williams, A.P.; Cook, E.R. Oceanic and Radiative Forcing of Medieval Megadroughts in the American Southwest. Sci. Adv. 2019, 5, 87. [CrossRef]

5. Buchanan, R.C.; Wilson, B.B.; Robert, R.B.; Butler, J.J., Jr. The High Plains Aquifer. In Public Information Circular 18; Kansas Geological Survey: Lawrence, KS, USA, 2018; Available online: http://www.kgs.ku.edu/ Publications/pic18/PIC18R2.pdf (accessed on 11 April 2018).

6. Haacker, E.; Anthony, K.; Hyndman, D. Water Level Declines in the High Plains Aquifer: Predevelopment to Resource Senescence. Groundwater 2016, 54, 231-242. [CrossRef] [PubMed]

7. Padget, S. The Water/Energy/Carbon Nexus and Triple Bottom Line Solutions. In Proceedings of the Global Water: Drought, Conservation and Security in the 21st Century Conference, Lawrence, KS, USA, 12 April 2013.

8. Steward, D.R.; Bruss, P.J.; Yang, X.; Staggenborg, S.A.; Welch, S.M.; Apley, M.D. Tapping Unsustainable Groundwater Stores for Agricultural Production in the High Plains Aquifer of Kansas, Projections to 2110. Proc. Natl. Acad. Sci. USA 2013, 110, 3477-3486. [CrossRef] [PubMed]

9. Peterson, J.; Daniel, B. High Plains Regional Aquifer Study Revisited: A 20-Year Retrospective for Western Kansas. Gt. Plains Res. 2003, 13, 179-197.

10. Ashworth, W. Ogallala Blue: Water and Life on the High Plains; W.W. Norton \& Company: New York, NY, USA, 2006.

11. Logan, K.E.; Brunsell, N.A.; Jones, A.R.; Feddema, J.J. Assessing Spatiotemporal Variability of Drought in the US Central Plains. J. Arid Environ. 2010, 74, 247-255. [CrossRef]

12. Wilhite, D. Drought: Past and Future. In Drought in the Life, Cultures, and Landscapes of the Great Plains; University of Nebraska-Lincoln: Lincoln, NE, USA, 2014.

13. Lemley, A.; Wagenet, L. Rural Water Quality Database. J. Ext. 1993, 31, 11-13.

14. Expert Panel on Groundwater. The Sustainable Management of Groundwater in Canada; The Council of Canadian Academies: Ottawa, ON, Canada, 2009.

15. Corral-Verdugo, V.; Bechtelb, R.B.; Fraijo-Sing, B. Environmental Beliefs and Water Conservation: An Empirical Study. J. Environ. Psychol. 2003, 23, 247-257. [CrossRef]

16. Cottrell, S.P. Influence of Sociodemographic and Environmental Attitudes of General Responsible Environmental Behavior among Recreational Boaters. Environ. Behav. 2003, 35, 347-375. [CrossRef]

17. Bamberg, S.; Moser, G. Twenty Years after Hines, Hungerford, and Tomera: A New Meta-Analysis of Psycho-Social Determinants of Pro-Environmental Behavior. J. Environ. Psychol. 2007, 27, 14-25. [CrossRef]

18. Hiramatsu, A.; Kurisu, K.; Hanaki, K. Environmental Consciousness in Daily Activities Measured by Negative Prompts. Sustainability 2016, 8, 24. [CrossRef] 
19. Liobikiene, G.; Poskus, M.S. The Importance of Environmental Knowledge for Private and Public Sphere Pro-Environmental Behavior: Modifying the Value-Belief-Norm Theory. Sustainability 2019, 11, 3324. [CrossRef]

20. Thogersen, J.; Olander, F. To What Degree are Environmentally Beneficial Choices Reflective of a General Conservation Stance? Environ. Behav. 2006, 38, 550-569. [CrossRef]

21. Whitmarsh, L.; O'Neill, S. Green Identity, Green Living? The Role of Pro-Environmental Self-Identity in Determining Consistency across Diverse Pro-Environmental Behaviors. J. Environ. Psychol. 2010, 30, 305-314. [CrossRef]

22. Kennedy, E.H.; Givens, J.E. Eco-Habitus or Eco-Powerlessness? Examining Environmental Concern across Social Class. Sociol. Perspect. 2019. [CrossRef]

23. Truelove, Y. (Re-)Conceptualizing Water Inequality in Delhi, India through a Feminist Political Ecology Framework. Geoforum 2011, 42, 143-152. [CrossRef]

24. Littig, B. Feminist Perspectives on Environment and Society; Pearson Education Limited: Harlow, UK, 2001.

25. Dzialo, E. The Feminization of Environmental Responsibility. Master's Thesis, Washington State University, Washington, DC, USA, 2016.

26. Southerton, D.; Warde, A.; Hand, M. The Limited Autonomy of the Consumer: Implications for Sustainable Consumption. In Sustainable Consumption: The Implications of Changing Infrastructure Provision; Southerton, D., Chappells, H., van Vliet, B., Eds.; Edward Elgar: Northampton, MA, USA, 2004.

27. Maupin, M.A.; Kenny, J.F.; Hutsson, S.S.; Lovelace, J.K.; Barber, N.L.; Linsey, K.S. Estimated Use of Water in the US in 2010. In US Geological Survey Circular 1405; US Geological Survey: Reston, VA, USA, 2014.

28. Smith, C.S. City Water, City Life: Water and the Infrastructure of Ideas in Urbanizing Philadelphia, Boston, and Chicago; University of Chicago Press: Chicago, IL, USA, 2013.

29. Imgrund, K.; Kreutzwiser, R.; Loe, R. Influences on the Water Testing Behaviours of Private Well Owners. J. Water Health 2011, 9, 241-252. [CrossRef] [PubMed]

30. Vannini, P.; Taggart, J. Onerous Consumption: The Alternative Hedonism of Off-Grid Domestic Water Use. J. Consum. Cult. 2016, 16, 80-100. [CrossRef]

31. Brown, K.P. Water, Water Everywhere (or, Seeing Is Believing): The Visibility of Water Supply and the Public Will for Conservation. Nat. Cult. 2017, 12, 219-245. [CrossRef]

32. Fine, B. The World of Consumption: The Material and Cultural Revisited, 2nd ed.; Routledge: London, UK, 2002.

33. Guy, S.; Marvin, S. Constructing Sustainable Urban Futures: From Models to Competing Pathways. Impact Assess. Proj. Apprais. 2001, 19, 131-139. [CrossRef]

34. Medd, W.; Shove, E. The Sociology of Water Use. UKWIR Report Ref No: 07/CU/02/2. Available online: https://ukwir.org/reports/07-CU-02-2/66661/The-Sociology-of-Water-Use (accessed on 31 January 2007).

35. Gandy, M. The Fabric of Space: Water, Modernity, and the Urban Imagination; The MIT Press: Cambridge, MA, USA, 2014.

36. Wright, L. Clean and Decent: The Fascinating History of the Bathroom and the Water Closet; Routledge and Kegan Paul: London, UK, 1960.

37. Prud'Homme, A. The Ripple Effect: The Fate of Freshwater in the Twenty-First Century; Scribner: New York, NY, USA, 2011.

38. Heidenreich, E. Fliessraume: Die Vernetzung Von Nature, Raum Und Gesellschaft Seit Dem 19. Jahrhundert; Campus Verlag: Frankfurt, Germany, 2004.

39. Shove, E. Comfort, Cleanliness and Convenience: The Organization of Normality; Berg Press: New York, NY, USA, 2003.

40. Bakker, K.J. Privatizing Water: Governance Failure and the World's Urban Water Crisis; Cornell University Press: Ithaca, NY, USA, 2010.

41. Makki, A.; Stewart, R.; Panuwatwanich, K.; Beal, C. Revealing the Determinants of Shower Water End Use Consumption: Enabling Better Targeted Urban Water Conservation Strategies. J. Clean. Prod. 2013, 60, 129-146. [CrossRef]

42. Ternes, B. Groundwater Citizenship and Water Supply Awareness: Investigating Water-Related Infrastructure and Well Ownership. Rural Sociol. 2018, 83, 347-377. [CrossRef]

43. Murti, M.; Yard, E.; Kramer, R.; Haselow, D.; Mettler, M.; McElvany, R.; Martin, C. Impact of the 2012 Extreme Drought Conditions on Private Well Owners in the United States, A Qualitative Analysis. BMC Public Health 2016, 16, 430. [CrossRef] [PubMed] 
44. VanDerslice, J. Drinking Water Infrastructure and Environmental Disparities: Evidence and Methodological Considerations. Am. J. Public Health 2011, 101, 109-114. [CrossRef] [PubMed]

45. Fox, M.; Keeve, E.; Anderson, N.B.; Lam, J.; Resnick, B. Meeting the Challenge of Protecting Private Wells: Proceedings and Recommendations from an Expert Panel Workshop. Sci. Total Environ. 2016, 554, 113-118. [CrossRef] [PubMed]

46. Ghazali, E.M.; Nguyen, B.; Mutum, D.S.; Yap, S.F. Pro-Environmental Behaviors and Value-Belief-Norm Theory: Assessing Unobserved Heterogeneity of Two Ethnic Groups. Sustainability 2019, 11, 3237. [CrossRef]

47. Hao, F.J.; Michaels, L.; Bell, S.E. Social Capital's Influence on Environmental Concern in China: An Analysis of the 2010 Chinese General Social Survey. Sociol. Perspect. 2019. [CrossRef]

48. Mollinga, P. Water, Politics and Development: Framing a Political Sociology of Water Resources Management. Water Altern. 2008, 1, 7-23.

49. Carfagna, L.B.; Dubois, E.A.; Fitzmaurice, C.; Ouimette, M.Y.; Schor, J.B.; Willis, M.; Laidley, T. An Emerging Eco-habitus: The Reconfiguration of High Cultural Capital Practices among Ethical Consumers. J. Consum. Cult. 2014, 14, 158-178. [CrossRef]

50. Nguyen, H.D.; Ngo, T.; Le, T.D.; Ho, H.; Nguyen, H.T. The Role of Knowledge in Sustainable Agriculture: Evidence form Rice Farms' Technical Efficiency in Hanoi, Vietnam. Sustainability 2019, 11, 2472. [CrossRef]

51. Johnson, E.W.; Schwadel, P. It Is Not a Cohort Thing: Interrogating the Relationship between Age, Cohort, and Support for the Environment. Environ. Behav. 2018, 51, 879-901. [CrossRef]

52. Choi, H.J.; Jang, J.; Kandampully, J. Application of the Extended VBN Theory to Understand Consumers' Decisions about Green Hotels. Int. J. Hosp. Manag. 2015, 51, 87-95. [CrossRef]

53. Nowak, M.A. Five Rules for the Evolution of Cooperation. Science 2006, 314, 1560-1563. [CrossRef] [PubMed]

54. Corral-Verdugo, V.; Frias-Armenta, M.; Perez-Urias, F.; Orduna-Cabrera, V.; Espinoza-Gallego, N. Residential Water Consumption, Motivation for Conserving Water and the Continuing Tragedy of the Commons. Environ. Manag. 2002, 30, 527-535. [CrossRef]

55. Niva, V.; Taka, M.; Varis, O. Rural-Urban Migration and the Growth of Informal Settlements: A Socio-Ecological System Conceptualization with Insights Through a 'Water Lens'. Sustainability 2019, 11, 3487. [CrossRef]

56. Larsen, T.; Hoffmann, S.; Luthi, C.; Truffer, B.; Maurer, M. Emerging Solutions to the Water Challenges of an Urbanizing World. Science 2019, 352, 928-933. [CrossRef]

57. Ternes, B. Saving for a Dry Day: Investigating Well Ownership and Watering Practices during Droughts. Environ. Sociol. 2019, 5, 93-107. [CrossRef]

58. Little, T.D. Longitudinal Structural Equation Modeling; Guilford: New York, NY, USA, 2013.

59. Kollmuss, A.; Agyman, J. Mind the Gap: Why do People Act Environmentally and What are the Barriers to Pro-Environmental Behavior? Environ. Educ. Res. 2002, 8, 239-260. [CrossRef]

60. Corral-Verdugo, V. Dual 'Realities' of Conservation Behavior: Self-Reports vs. Observations of Re-Use and Recycling Behavior. J. Environ. Psychol. 1997, 17, 135-145. [CrossRef] 